\title{
Kegiatan Jam'iyah Shalawat Solusi Pembentukan Akhlakul Karimah Remaja Di Jatirejo Diwek Jombang
}

\author{
Ali Mustofa dan Ika Khoirunni'mah \\ Sekolah Tinggi Ilmu Tarbiyah Al Urwatul Wutsqo Jombang, Indonesia \\ e-mail: aljep_90@yahoo.com, e-mail: Ikakhoir3@gmail.com
}

\begin{abstract}
Congregation of shalawat, the term itself only appeared around the mid 2000s and above. Previously, the public was more familiar with the terms diba'an, float and so on. The terms of prayer and prayer are very familiar to the people of Indonesia, especially Muslims. Formation of adolescent morality akhakul through activities jam'iyah shalawat Ds. Jatirejo Kec. Diwek Kab. Jombang, the efforts that can be made to establish morality are: Through the habituation process. Intercommunication with people who have noble character (noble character) who are in the environment around the residence and through the teaching process (spiritual splash). adolescents behave well as a polite example to older people and can sort out something good and something bad to do. Supporting factors faced by Jatirejo village adolescents in the efforts to establish the morality of adolescents through adolescent jam'iyah shalawat activities namely the existence of facilities that can support the activities, and most importantly the motivation or interest possessed by adolescents so that in the process of moral formation takes place and makes him moved to follow the activity. Meanwhile, the inhibiting factor is the decline in motivation in participating in activities and also environmental factors due to unfavorable interactions.
\end{abstract}

Keywords: Congregation of blessings, akhlakul karimah

\section{Pendahuluan}

Akhlak, selalu dikaitkan dengan tingkah laku manusia. Atau dengan kata lain akhlak merupakan sesuatu yang sangat penting bagi kehidupan manusia. Orang akan terlihat mulia bergantung kepada bagaimana akhlaknya, sehingga akhlak memiliki kedudukan yang sangat penting (Djatmika, 1996).

Akhlak merupakan salah satu tujuan pokok agama Islam, Islam menjadikan baik buruknya akhlak seseorang sebagai bukti dan buahnya ibadah kepada Allah. Sehingga 
dapat membentuk kepribadian seorang muslim yang berakhlak mulia, baik secara lahiriah maupun batiniah (Ilyas, 2001).

Rasulullah bersabda :

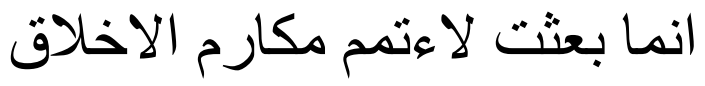

Artinya: "Sesungguhnya aku diutus untuk menyempurnakan akhlak yang mulia”.

Hadits tersebut dapat dijadikan sebagai alasan bahwa akhlak itu penting bagi manusia dalam mencapai kebahagian hidup di dunia dan akhirat. Dalam Al-Qur'an juga terdapat petunjuk tentang Nabi Muhammad diutus oleh Allah untuk menyempurnakan akhlak. Sebagaimana firmannya dalam surah Al-Ahzab:

Artinya: "Sesungguhnya telah ada pada (diri) Rasulullah itu suri teladan yang baik bagimu (yaitu) bagi orang yang mengharap (rahmat) Allah dan (kedatangan) hari kiamat dan Dia banyak menyebut Allah" (QS: Al-Ahzab).

Ayat ini menunjukkan bahwa pembinaan akhlak tidak dapat ditegakkan jika hanya menyampaikan ajaran-ajaran, atau perintah-perintah dan larangan saja. Melainkan yang terpenting yakni perlu adanya keteladanan atau pemberian contoh perilaku yang baik dan pengamatan untuk mencapai hasil yang baik.

Pengertian di atas memberi gambaran bahwa tingkah laku merupakan bentuk kepribadian seseorang tanpa dibuat-buat atau spontan atau tanpa ada dorongan dari luar. Jika baik menurut pandangan akal dan agama, tindakan spontan itu dinamakan akhlak yang baik (al-akhlakul karimah / al-akhlakul mahmudah), sebaliknya jika tindakan spontan itu buruk disebut (al-akhlakul madzmumah) (Anwar, 2010).

Realita yang terjadi sekarang ini, pembinaan atau pembentukan akhlak semakin terasa diperlukan dimana semakin banyak tantangan dan godaan sebagai dampak dari kemajuan yang pesat. Peristiwa yang baik atau yang buruk dengan mudah dapat diakses melalui internet, televisi, film, buku-buku dan tempat hiburan yang menyuguhkan adegan maksiat juga banyak. Disinilah letak pentingnya akhlak seseorang, sebab seseorang yang memiliki ilmu pengetahuan dan teknologi yang maju disertai dengan akhlakul karimah niscaya ilmu pengetahuan dan teknologi modern yang ia miliki akan dimanfaatkan sebaik-baiknya untuk kebaikan hidup manusia. Sebaliknya orang yang 
memiliki ilmu pengetahuan dan teknologi modern, harta, kekuasaan namun tidak disertai dengan akhlakul karimah maka semua itu akan disalah gunakan yang mengakibatkan timbulnya bencana dimuka bumi (Nata, 2012).

Dalam menyikapi permasalahan yang dihadapi oleh remaja perlu adanya pembinaan, untuk mewujudkannya dalam membentuk akhlak mulia, diperlukan kerja sama antar pihak yang terlibat seperti keluarga atau orang tua, sekolah dan masyarakat. Agar terwujud diperlukan berbagai upaya antara lain meningkatkan ilmu pendidikan dan pendidikan keagamaan, khususnya pendidikan akhlakul karimah serta ilmu pendidikan tentang iman dan taqwa dengan memperdalam pengetahuan dan meningkatkan pengalaman tentang ajaran nilai-nilai Islam dalam membentuk akhlak mulia. Hal itu dilakukan karena didalam jiwa seseorang terdapat sisi negatif untuk mengikuti perintah nafsu dan syahwat yang selalu mengancam keutuhan kepribadian diri manusia. Maka perlu pembentukan akhlak melalui kegiatan keagamaan.

Untuk membina remaja, khususnya remaja muslim, terdapat banyak hal yang bisa dilakukan, salah satunya melalui kegiatan jam'iyah shalawat. Shalawat merupakan ibadah sunnah yang paling mulia yang terdapat banyak sekali pahala dan keutamaannya. Sebagai bentuk penghormatan kepada Rasulullah SAW. Melalui kegiatan ini, mereka dapat membentuk lingkungan Islami (Jaelani, 2015).

Kata jam'iyah berasal dari organisasi (jama'ah) ialah salah satu jalan untuk mencapai cita-cita personal maupun kelompok, dimana segala sesuatu dikaitkan dengan nama organisasi yang dianggap berpengaruh dimana suatu kondisi masih melekat dalam kehidupan sosial dan dianggap sebagai keharusan suatu organisasi untuk memperlancar rencana dan tujuan. Pada awalnya, organisasi menjadi lembaga, wadah dan mengarahkan pada pengembangan diri dimana seseorang dengan organisasi yang berwawasan luas, berfikir panjang dan cakap. Namun berbeda dengan keadaan sekarang, dimana sangat mudah mengumpulkan atau membentuk organisasi tersebut atau biasa disebut Jam'iyah. Makna jam'iyah dalam organisasi adalah nilai kebersamaan yang bisa diterima tanpa ada perbedaan pola fikir yang disatukan sehingga menghasilkan rembuk atau musayawarah mufakat itu sendiri dalam Islamnya (Dahri, diakses 25 maret 2016). 
Jama'ah shalawat, istilah itu sendiri baru muncul sekitar pertengahan tahun 2000 an ke atas. Sebelumnya, masyarakat lebih mengenal istilah diba'an, terbangan dan sebagainya. Istilah shalawat dan shalat sudah sangat akrab diketahui masyarakat Indonesia terutama umat islam. Pemahaman mereka, terhadap keduanya memiliki maksud yang berbeda. Mereka mengartikan shalat dengan sembahyang, sedangkan shalawat dipahami dengan bacaan yang ditujukan dengan niat berdo'a bagi Nabi Muhammad SAW. Padahal, telah dikemukakan, shalawat jamak dari kata shalat.

Setelah memperhatikan, bahwa pembentukan kepribadian tidak hanya dititik beratkan pada pihak sekolah saja terutama bagi guru agama melainkan diperlukan tiga unsur pendidikan yang ikut andil didalamnya meliputi keluarga, sekolah maupun masyarakat. Dari ketiga unsur tersebut terdapat kesadaran masing-masing pihak untuk saling melengkapi dalam mewujudkan insan yang memiliki kepribadian luhur (Soparno, 2015). Agar mereka menjadi generasi yang bermoral religius, maka harus dibina, dibimibing dan dilatih dengan baik dan benar.

Dalam hal ini, maka nilai - nilai akhlak yang mulia hendaknya ditanamkan sejak dini melalui pendidikan agama dan diawali dalam lingkungan keluarga melalui pembudayaan dan pembiasaan. Kebiasaan ini dapat dikembangkan dalam pergaulan hidup bermasyarakat dan disekolah. Disini diperlukan kepeloporan para pemuka agama serta lembaga- lembaga keagamaan yang dapat mengambil peran terdepan dalam membina akhlak mulia.

\section{Pembahasan}

\section{Perspektif Teoritik}

\section{Tinjauan Tentang Akhlakul Karimah}

\section{a. Pengertian Akhlakul Karimah}

Akhlak secara bahasa adalah perangai, tingkah laku dan tabiat. Namun, secara istilah akhlak adalah tata cara pergaulan atau bagaimana seorang hamba berhubungan dengan Allah sebagai penciptanya, dan bagaimana seorang hamba bergaul dengan sesama manusia lainnya (Hasan, 2002).

Adapun pengertian akhlak menurut ulama' antara lain sebagai berikut: 
1) Menurut Imam Ghazali dalam buku (Beni Ahmad Saebani, 2010) mengatakan bahwa akhlak adalah sifat yang tertanam dalam jiwa seseorang yang menimbulkan macam- macam perbuatan dengan spontan dan mudah, tanpa memerlukan pemikiran dan pertimbangan.

2) Menurut Ibn Miskawaih dalam buku (Beni Ahmad Saebani, 2010) mengatakan bahwa akhlak adalah sifat yang tertanam dalam jiwa seseorang yang mendorongnya untuk melakukan perbuatan- perbuatan tanpa memerlukan pemikiran dan pertimbangan terlebih dahulu.

Sedangkan, pengertian akhlak ada beberapa devinisi yang telah dikemukakan oleh para ahli antara lain:

1) Menurut M. Quraish Shihab dalam buku (Shihab, 2007), kata akhlak diartikan sebagai budi pekerti atau kelakuan. Kata akhlak walaupun terambil dalam bahasa Arab (yang bisa diartikan tabiat, perangai, kebiasaan, bahkan agama), namun kata seperti itu tidak ditemukan dalam Al-Qur'an. Yang ditemukan hanyalah bentuk tunggal kata tersebut yaitu khuluq.

Akhlak dalam ajaran agama tidak disamakan dengan etika, karena etika dibatasi pada sopan santun antar sesame manusia, serta hanya berkaitan dengan tingkah laku lahiriah. Misalnya yang berkaitan dengan sikap, batin maupun pikiran. Akhlak agama (diniah) mencakup berbagai aspek, dimulai dari akhlak terhadap Allah, hingga kepada sesama makhluk (manusia, binatang, tumbuh-tumbuhan, dan benda-benda tak bernyawa).

2) Menurut Barmawi Umari dalam buku (Umari, 1976), akhlak merupakan ilmu yang menentukan batasan baik dan buruknya seseorang, terpuji dan tercelanya perbuatan atau perkataan manusia secara lahir dan batin.

Islam sangat mementingkan akhlak karena dengan adanya akhlak manusia dapat melakukan sesuatu tanpa menyakiti atau menzalimi orang lain dalam setiap tindakannya selama bergaul dengan manusia dan makhluk Allah yang lain.

Akhlak adalah ruh bagi Islam. Agama tanpa akhlak sama seperti jasad tanpa nyawa. ilmu tanpa akhlak atau adab, ibarat api tanpa kayu bakar. Dan 
akhlak, tanpa ilmu bagaikan jiwa tanpa jasad. Oleh sebab itu, kita sebagai hamba Allah yang diberikan akal pikiran sudah sewajarnya melakukan sesuatu yang tidak sama dengan yang dilakukan hewan karena binatang adalah makhluk yang tidak dikenakan hukum atas mereka.

3) Menurut Wahid Ahmadi Istikah dalam buku (Istikah, 2004), akhlak secara istilah dari bahasa arab yang merupakan kata jamak dari bentuk tunggal khuluk, pengertian secara umumnya; baik perilaku terpuji maupun perilaku tercela. Selanjutnya Wahid Ahmadi mengutip pendapat Imam Ghazali dalam buku risalah akhlak menyatakan:

"khuluq adalah kondisi jiwa yang telah tertanam kuat, yang terlahir sikap amal secara mudah tanpa membutuhkan pemikiran dan pertimbangan".

Dikisahkan oleh Ruwaim Ibnu Ahmad Al-Baghdadi dalam buku (Abdurrahman, 2016) berkata kepada anaknya, “ Wahai anakku, jadikanlah amalmu ibarat garam, akhlakmu ibarat tepung (perbanyaklah akhlakmu), sehingga ia menjadi bagian yang besar dalam perilakumu, sebagaimana banyaknya tepung dari garam yang diletakkan didalamnya. Banyak akhlak ( yang kamu miliki) dengan sedikit amal saleh, lebih baik daripada banyak amal saleh tetapi sedikit atau tidak punya akhlak.

Sedangkan "Karimah" dalam bahasa Arab artinya terpuji, baik atau mulia. Berdasarkan pengertian dari akhlak dan karimah, dapat disimpulkan bahwa akhlakul karimah adalah segala budi pekerti baik yang ditimbulkan tanpa melalui pemikiran dan pertimbangan yang mana sifat itu menjadi budi pekerti yang utama yang dapat meningkatkan harkat dan martabat manusia.

\section{b. Pembagian Akhlak}

Akhlak pada pokoknya terbagi menjadi dua, yakni akhlak mahmudah atau akhlakul karimah (terpuji) dan akhlak madzmumah atau akhlak sayyi'ah (tercela) (Jamhari, 1999). 
1) Akhlak Mulia.

Sifat-sifat terpuji yang terdapat pada orang mukmin sebagai bukti tanda sempurnanya iman seseorang atau perbuatan terpuji menurut pandangan akal dan syariat Islam.

Termasuk akhlak mulia antara lain: mengabdi kepada Allah SWT, ikhlas dalam beramal, mengerjakan kebaikan dan menjauhi larangan-larangan karena Allah SWT, berbakti kepada kedua orang tua, sabar, jujur, pemaaf, dermawan, amanah dan lain sebagainya menurut pandangan Islam.

2) Akhlak Tercela

Termasuk akhlak yang tidak baik atau akhlak yang dapat merusak iman seseorang dan menjatuhkan martabat manusia dari pandangan Allah SWT, Rasulnya maupun sesama manusia. Diantaranya perbuatan tercela menurut pandangan Islam antara lain: berdusta, pemarah, pendendam, kikir, khianat, riya' dan lain-lain.

\section{c. Sasaran Akhlak}

1) Akhlak Kepada Allah

Merupakan berserah diri hanya semata-mata kepada Allah SWT, bersabar atas segala cobaan dan pemberiannya, ridha terhadap hukum-Nya atau syari'at-Nya, baik dalam masalah takdir, dan tidak pernah keberatan terhadap takdir-Nya dan juga terhadap hukum-Nya yaitu syariat Islam (AlHamd, 2002).

Ringkasnya berakhlak terhadap Allah adalah :

a) Menjalankan segala perintah-Nya dan meninggalkan segala laranganNya serta waspada terhadap larangan tersebut.

b) Cermat dalam segala perantara atau sebab yang dapat mendekatkan seorang hamba kepada Tuhannya, dan menjadikan-Nya sebagai kekasihnya.

c) Menghindari diri dari perbuatan yang dilarang-Nya. Karena perbuatan yang dilarang menggiring manusia untuk mengikuti nafsu amarah. Dan 
melawan nafsu adalah perbuatan yang sangat sulit dilakukan jika keimanan seseorang tidak stabil.

2) Akhlak terhadap Rasulullah

Rasulullah SAW menjadi uswatun hasanah atau suri tauladan bagi seluruh manusia. Yang disebutkan dalam Al-Qur'an dalam Surat Al-Qalam ayat 4.

Akhlak terhadap Rasulullah antara lain:

a) Mencintai Rasulullah secara tulus dengan mengikuti semua sunnahnya.

b) Menjadikan Rasulullah sebagai idola, suri tauladan dalam kehidupan.

c) Menjalankan apa yang disuruhnya, tidak melakukan apa yang dilarangnya.

3) Akhlak Kepada Orang Tua

Adanya keturunan sebab Orang tua, karena itu Allah memberikan keistemewaan untuk memuliakan kedua orang tua terutama pada Ibu. Bahkan berdosa terhadap orang tua adalah dosa besar yang siksanya diakhirat dan didunia juga.

Prinsip- prinsip dalam melaksanakan akhlak mahmudah terhadap orang tua:

a) Patuh, mentaati perintah-Nya terkecuali yang bertentangan dengan perintah Allah.

b) Ihsan, berbuat baik kepada mereka sepanjang masa.

c) Lemah lembut dalam bertutur kata dan berbuat.

d) Merendahkan diri dihadapannya.

e) Berterima kasih

f) Berdo'a sebagai bentuk Birrul Walidain (berbakti kepada orang tua).

4) Akhlak Kepada Sesama Manusia

Manusia adalah makhluk sosial, karena itu manusia membutuhkan orang lain dalam bermasyarakat, maka dibutuhkan akhlak terhadap sesama manusia diantaranya berbuat baik terhadap sesama, saling tolong menolong, menjaga lisan dan tangan supaya tidak menyakiti yang lain. 
Kegiatan Jam'iyah Shalawat

5) Akhlak Terhadap Lingkungan

Hubungan antara manusia dengan manusia lainnya. Sehingga, dibutuhkan akhlak terhadap lingkungan yaitu:

a) Hormat kepada Orang lain

Manusia tidak dapat hidup sendiri. Karena manusia tidak mungkin bisa memenuhi kebutuhan hidupnya, maka diperlukan bantuan orang lain untuk memenuhi kebutuhan, sehingga kita harus saling menghormati (Umary, 1991).

b) Menjenguk Orang sakit

Rasulullah SAW memerintahkan untuk menjenguk orang sakit sebagai bentuk tali persaudaraan sesama muslim dan termasuk salah satu hak dan kewajiban terhadap saudara (Ali, 1992).

\section{d. Faktor-Faktor Pembentukan Akhlak}

Untuk menjelaskan faktor- faktor yang mempengaruhi pembentukan akhlak, ada tiga aliran, meliputi:

1) Aliran Nativisme

Menurut aliran nativisme faktor yang berpengaruh terhadap pembentukan diri seseorang yakni faktor pembawaan dari dalam berupa kecenderungan, bakat, akal dan lain-lain.

Aliran ini tampaknya begitu yakin terhadap potensi batin yang ada dalam diri manusia, dan hal ini kelihatannya erat berkaitan dengan aliran intuisme dalam hal penentuan baik dan buruk.

2) Aliran Empirisme

Menurut aliran empirisme faktor yang berpengaruh terhadap pembentukan diri seseorang adalah faktor dari luar, yaitu lingkungan sosial, termasuk pembinaan dan pendidikan yang diberikan.

3) Aliran Konvergensi

Pembentukan akhlak dipengaruhi oleh faktor internal, yaitu pembawaan si anak, dan faktor dari luar yaitu pendidikan dan pembinaan yang dibuat secara khusus, atau melalui interaksi dalam lingkungan sosial (Nata, 2012). 


\section{Tinjauan Tentang Masa Remaja}

Masa remaja merupakan masa peralihan dari masa anak-anak menuju masa dewasa, dengan dimulainya tanda baligh (terjadinya kematangan seksual) yaitu usia 11 atau 12 tahun sampai dengan 20 tahun yang menjelang masa dewasa muda (Soetjiningsih, 2004).

Selain adanya perubahan fisik, terdapat adanya perubahan baik dari dalam maupun dari luar dirinya yang menjadikan kebutuhan remaja semakin meningkat terutama dari segi kebutuhan sosial dan dan psikologinya. Kondisi ini merupakan reaksi terhadap pertumubuhan. Hal ini menjadikan remaja diharapkan mampu untuk menampilkan tingkah laku yang dianggap pantas atau sesuai dengan seusianya. Untuk memenuhi kebutuhan, remaja diharapkan mampu memperluas baik dilingkungan masyarakat dan lingkungan teman sebaya (Agustina, 2006).

Secara umum masa remaja terbagi menjadi tiga bagian, yaitu:

a. Remaja awal (12-15 tahun)

Masa remaja ini dimulai dengan meninggalkan peran sebagai anak-anak dan berusaha mengembangkan diri sebagai individu yang tidak bergantung pada orang tua. Focus dari tahap ini adalah penerimaan terhadap bentuk dan kondisi fisik serta adanya konformitas yang kuat dengan teman sebaya.

b. Remaja pertengahan (15-18 tahun)

Masa remaja ini ditandai dengan adanya perkembangan dalam kemampuan berfikir yang baru. Peran penting teman sebaya masih dimiliki, namun individu lebih cenderung mengarahkan dirinya sendiri. Pada tahap ini remaja mulai mengembangkan kematangan tingkah laku, dapat membuat keputusankeputusan yang berkaitan dengan tujuan yang ingin dicapai. Dalam hal ini lawan jenis menjadi penting bagi individu.

c. Remaja akhir (18-22 tahun)

Pada masa ini ditandai dengan persiapan akhir untuk memasuki peran-peran dewasa. Selama periode ini remaja berusaha kearah pemantapan tujuan dan pengembangan. Keinginan kuat untuk menjadi matang agar dapat diterima 
dalam kelompok teman sebaya dan orang dewasa, juga menjadi cirri dalam tahap ini.

\section{Tinjauan tentang Jam'iyah Shalawat}

\section{a. Pengertian Shalawat}

Shalawat dalam pandangan Islam merupakan suatu do'a permohonan kepada Allah SWT untuk nabi Muhammad SAW, sebagai bukti dari rasa hormat dan cinta kepadanya. Shalawat merupakan perintah Allah SWT, dan orang-orang yang bershalawat kepada nabi Muhammad SAW, akan menerima pahala dan syafa'at (pertolongan) (Kinosyan, 2002).

Dalam Q.S: Al-Ahzab ayat 56, Allah berfirman:

Artinya: "Sesungguhnya Allah dan malaikat-malaikat-Nya bershalawat untuk Nabi. Hai orang-orang yang beriman, bershalawatlah kamu untuk Nabi dan ucapkanlah salam penghormatan kepadanya".

Bershalawat artinya: kalau dari Allah berarti memberi rahmat: dari Malaikat berarti memintakan ampunan dan kalau dari orang-orang mukmin berarti berdoa supaya diberi rahmat seperti dengan perkataan: Allahuma shalli ala Muhammad.

Adapun pendapat lain mengatakan bahwa, shalawat adalah bentuk jamak dari kata shalat yang bermakna do'a, keberkahan, kemulian, kesejahteraan, dan ibadah. Bershalawat dapat diartikan dengan melihat dari perilakunya. Jika shalawat itu datangnya dari Allah SWT, berarti member rahmat kepada makhluknya. Sedangkan shalawat dari orang-orang mukmin berarti suatu do'a agar Allah SWT memberi rahmat dan kesejahteraan kepada Nabi Muhammad saw beserta keluarganya. Selain itu shalawat juga do'a untuk diri sendiri, orang banyak, maupun kepentingan bersama. Adapun shalawat sebagai ibadah adalah pernyataan hamba atas ketundukannya kepada Allah SWT serta mengharapkan pahala dari-Nya, sebagaimana yang telah dijanjikan Nabi Muhammad saw bahwa orang bershalawat kepadanya akan mendapat pahala yang besar, baik shalawat itu dalam bentuk tulisan maupun ucapan (lisan). 


\section{b. Kemuliaan Shalawat}

Shalawat yang ditujukan kepada Nabi Muhammad, mengandung beberapa kemuliaan, antara lain:

1) Allah SWT, sendiri yang membaca shalawat kepada Nabi Muhammad saw.

2) Ada syafaat yang berasal dari Nabi pilihan. Nabi Muhammad SAW, itu termasuk Nabi pilihan diantara para Nabi dan Rasul lainnya.

3) Mengikuti apa yang dilakukan oleh para malaikat yang baik dan taat kepada Tuhannya.

4) Shalawat itu bertentangan dengan perbuatan orang munafik dan orang kafir.

5) Shalawat dapat menghapus kesalahan dan dosa.

6) Shalawat dapat memenuhi kebutuhan hajat kita.

7) Menyinari lahir dan batin agar terang dan bisa menerima kebenaran.

8) Shalawat membuat kita selamat dari siksa api neraka.

9) Shalawat bisa membuat kita masuk surge.

10) Mendapat salam dari Allah SWT, Tuhan Penguasa Alam Yang Maha Pengampun.

Tidak ada permohonan seorang hamba didunia ini yang dikabulkan Allah SWT, tanpa shalawat. Selain mengabulkan permohonan hamba yang teriringi shalawat. Allah SWT, juga akan menghindarkan 70 macam musibah dari badannya, agamanya, hartanya, dan keluarganya. Serta Allah SWT menjamin untuk diangkat derajatnya sebanyak 70 kali di surga (Salim, 2008).

\section{c. Fungsi Shalawat}

Qadhi Iyadh dalam kitab Asy-Syifa sebagaimana dikutip oleh ustadz Mahmud Samiy mengatakan bahwa maksud pembacaan shalawat dalam pembukaan segala sesuatu adalah:

1. Bertabaruk (memohon berkah), sesuai dengan sabda Rasulullah saw yang diriwayatkan oleh Rahawi yang artinya "setiap perbuatan penting yang tidak dimulai dengan menyebut nama Allah dan bershalawat kepadaku niscaya kurang sempurna”. Firman Allah dalam Qs. Al-Insyirah ayat 4 berbunyi: 
Artinya: "Dan Kami tinggikan bagimu sebutan (nama)Mu" (QS: AlInsyirah. 4).

Demikian pula sahabatAbu Salad Ra, menjelaskan bahwa makna ayat diatas adalah " tidaklah aku (Allah) disebut, melainkan engkau (Muhammad) pun disebut pula bersama-Ku."

2. Memenuhi sebagian hak Rasulullah Saw, sebab beliau adalah perantara antara Allah swt dengan hamba-hambanya, semua nikmat yang diterima oleh mereka termasuk nikmat terbesar berupa hidayah Islam yaitu yaitu dengan perantara melalui Rasulullah saw, dalam sebuah hadits Nabi bersabda, "Belum bersyukur kepada Allah orang-orang yang tidak berterima kasih kepada manusia".

3. Memenuhi perintah Allah Swt.

\section{Analisis Data}

\section{Upaya Pembentukan Akhlakul Karimah Remaja Melalui Kegiatan Jam'iyah Shalawat Ds. Jatirejo Kec. Diwek Kab. Jombang}

Pentingnya pembentukan akhlakul karimah pada remaja, dapat dilihat dari situasi kompleksitas kehidupan saat ini, yang secara langsung atau tidak langsung mempengaruhi kehidupan remaja. Pengaruh kompleksitas kehidupan terhadap remaja terlihat dari fenomena dampak kemajuan iptek yang sangat membutuhkan perhatian Islam terhadap pembinaan jiwa khususnya dalam upaya pembentukan akhlak. Sebagai salah satu upaya pembentukan akhlak yang diberikan kepada remaja demi menjaga potensi rohaniah yang terdapat dalam diri seseorang agar terbentuk pribadi-pribadi Muslim yang berakhlak mulia. Adanya kegiatan jam'iyah shalawat berfungsi sebagai bentuk pendekatan seseorang apabila mendambakan terwujudnya akhlak yang mulia. Oleh karena itu upaya pembentukan akhlakul karimah remaja melalui kegiatan jam'iyah shalawat sangat diperlukan bagi remaja, agar kedepannya terbiasa menjalankan kehidupan sesuai dengan ajaran Islam. 
Selain itu, dalam buku akhlak tasawuf (Nata, 2012) menjelaskan bahwa, pembentukan akhlak diartikan sebagai usaha sungguh-sungguh dalam rangka membentuk anak, dengan menggunakan sarana pendidikan dan pembinaan yang terpogram dengan baik dan dilaksanakan dengan sungguh-sungguh dan konsisten. Pembentukan akhlak ini dilakukan berdasarkan asumsi bahwa akhlak merupakan hasil usaha pembinaan, bukan terjadi dengan sendirinya. Potensi rohaniah yang ada dalam diri manusia, termasuk di dalamnya akal, nafsu amarah, nafsu syahwat, fitrah, kata hati, hati nurani dan intuisi dibina secara optimal dengan cara dan pendekatan yang tepat.

Berdasarkan data temuan yang diperoleh dilapangan bahwa adanya kegiatan jam'iyah shalawat di desa Jatirejo kecamatan Diwek kabupaten Jombang merupakan salah satu kegiatan remaja. Hal ini bertujuan untuk menumbuhkan rasa cinta kepada baginda Rasulullah, agar terlaksana dalam mencapai tujuan yang diinginkan, maka remaja berinisiatif untuk mengumpulkan beberapa remaja sekaligus untuk menambah keakraban atau kerukunan dalam satu desa. Dengan adanya kegiatan jam'iyah shalawat, secara perlahan menjadikan generasi remaja menjadi cinta akan shalawat, yang awalnya biasa saja menjadi tergugah dan sadar indahnya bershalawat. Sehingga, dapat membantu remaja lebih aktif dalam mengikuti kegiatan terutama dalam shalawat. Selain itu, dengan membiasakan bershalawat agar terbiasa untuk bershalawat. Adanya rutinan shalawat dapat dipandang sebagai pembiasaan remaja dalam pembentukan akhlak, sehingga kebiasaan adalah perbuatan yang diulangulang terus menerus sehingga mudah dikerjakan oleh seseorang, seperti kebiasaan berjalan, berbicara dan sebagainya (Mustafa, 1997). Karena remaja terbiasa dengan pelaksanaan kegiatan jam'iyah shalawat, kegiatan ini menjadikan kegiatan positif remaja lebih banyak, dan menjadikan remaja berteman dengan orang baik terutama membentuk kelompok pecinta shalawat.

Hal ini sejalan dengan pendapat (Ulwan, 1991) dalam bukunya yang berjudul pedoman mendidik anak dalam islam mengemukakan bahwa, pembentukan dapat ditekankan melalui nilai-nilai keagamaan. Terdapat beberapa metode yang dapat digunakan dalam penanaman nilai-nilai keagamaan pada anak, yaitu: 
a. Metode keteladanan

b. Metode adat kebiasaan

c. Metode nasihat

d. Metode pengawasan

e. Metode hukuman

Kegiatan atau aktivitas yang dilakukan dalam kehidupan sehari-hari, dapat memberikan dampak terhadap perkembangan diri di masa yang akan datang. Untuk itu diperlukan dalam memilih teman yang selalu mengajak kepada suatu kegiatan yang positif. Kegiatan tersebut misalnya berorganisasi, melakukan kegiatan, berbagi ilmu dan lain sebagainya. Hal itu dapat mengurangi kegiatan yang kurang bermanfaat contoh nongkrong. Hal ini disebabkan karena manusia memiliki sifat ingin meniru dan mencoba apa yang orang lain lakukan.

Sebagaimana hasil interview dengan saudara Aziz, selaku ketua jam'iyah shalawat BAPER,

Dengan diterapkannya rutinan shalawat, karena shalawat hal mendasar yang paling mudah untuk dilakukan dimanasemua pasti dapat bershalawat baik laki-laki maupun perempuan. Sehingga nilai-nilai religious dapat ditanamkan yaitu pembenahan akhlak, pembentukan remaja.

Pelaksanaan kegiatan jam'iyah shalawat desa Jatirejo itu diadakan setiap dua minggu sekali pada hari jum'at, kegiatan jam'iyah shalawat ini tidak hanya dilaksanakan didesa Jatirejo melainkan berkeliling didusun-dusun kelurahan Jatirejo. Dalam kegiatan remaja juga mendapatkan tambahan-tambahan materi tentang pendidikan keagamaan atau siraman rohani melalui ceramah, sehingga remaja mendapatkan pengalaman pelajaran dan hal baik lainnya.

Hasil pengamatan peneliti saat mengikuti kegiatan jam'iyah shalawat BAPER desa Jatirejo bahwa kegiatan ini tidak hanya dilaksanakan didesa Jatirejo melainkan berkeliling didusun-dusun diantaranya dusun Paculgowang, Wonosari dan Nanggungan. Shalawat ini tidak hanya bershalawat saja akan tetapi shalawat ini mengarah kepada B3 yaitu belajar, berjuang, bertaqwa sehingga shalawat ini berbentuk sekolah. 
Sudah dapat dirumuskan bahwa upaya pembentukan akhlakul karimah remaja melalui kegiatan jam'iyah shalawat adalah proses dalam melatih atau mendidik remaja dengan mempertahankan nilai dan norma yang positif dari remaja, dengan meningkatkan perilaku keagamaan mereka dengan cara menjaga akhlak yang luhur dan mulia. Sehingga sangat penting untuk dipelajari, dengan harapan nantinya remaja dapat menerapkan atau menjadikannya sebagai jalan kehidupan, baik pribadi maupun kehidupan masyarakat.

\section{Akhlak Yang Dimiliki Oleh Remaja Melalui Kegiatan Jam'iyah Shalawat Ds. Jatirejo Kec. Diwek Kab. Jombang}

Dalam suatu perkumpulan yang terdapat dalam majlis, remaja dituntut untuk menyuasaikan diri dalam bertingkah laku baik, sebagai bentuk pertimbangan manusia dalam masyarakat apakah baik atau buruk sesuai dengan yang diajarkan dalam Islam. Oleh karena itu, melalui kegiatan shalawat hendaknya memberikan kesempatan yang baik bagi remaja untuk melakukan hal tersebut secara baik dan benar. Dalam hal ini artinya remaja memiliki kebutuhan dan kemampuan serta kebiasaan untuk berkomunikasi dan berinteraksi dengan manusia lainnya. Dalam konteks ini, termasuk didalamnya adalah perilaku sosial adalah suasana saling ketergantungan yang merupakan keharusan untuk menjamin keberadaan manusia.

Akhlak yang harus dimiliki oleh remaja sebagai salah satu bukti bahwa manusia dalam memenuhi kebutuhan hidupnya, artinya bahwa kelangsungan hidup manusia berlangsung dalam suasana saling mendukung dalam kebersamaan. Untuk itu manusia diharapkan mampu bekerja sama, saling menghormati, tidak menggangu hak orang lain, serta toleran terhadap bermasyarakat. Oleh karena itu, program kegiatan shalawat di desa perlu memberikan wawasan luas bagi para remaja khususnya yang terdapat dilingkungan.

Adapun akhlak yang harus dimiliki remaja melalui kegiatan jam'iyah shalawat desa Jatirejo adalah untuk menerapkan perilaku yang mencerminkan kebaikan. Secara umum kebaikan merupakan sesuatu yang diharapkan, yang diusahakan menjadi salah satu tujuan manusia. Perilaku manusia tersebut mengarah pada kesempurnaan manusia (insan kamil) maka kebaikan itu disebut nilai (value). 
Menurut Mohammad Daud Ali, terdapat indicator perilaku sosial keagamaan, dilihat dari hubungan antara akhlak dengan masyarakat yaitu:

a. Menghargai Nilai dan Norma

Nilai merupakan standar umum yang diserap dari keadaan obyektif atau yang dianggap menjadi keyakinan, yang menjadi syarat umum. Sedangkan norma merupakan semacam keorganisasian seluruh lapisan masyarakat tentang kenyataan yang berlaku, maka setiap orang harus mampu menghargai dan menjunjung tinggi nilai dan norma agar masyarakat tentram dan damai. Apabila hal tersebut dikondisikan pada satu masyarakat, maka kedamaian dan ketentraman yang diinginkan akan tercipta dengan baik.

b. Saling tolong menolong dalam kebaikan

Sebagaimana telah kita ketahui bahwa manusia sebagai makhluk individu mempunyai hak pribadi yang orang lain tidak berhak ikut campur tangan. Sebagai makhluk sosial manusia memerlukan bantuan dalam memenuhi kebutuhan hidupnya.

c. Menunaikan amanah

Amanah berarti dapat dipercaya. Menunaikan amanah berarti melaksanakan kepercayaan yang diberikan seseorang atau masyarakat. Kepercayaan tidak dapat hanya berupa omongan semata (ucapan) akan tetapi diperlukan dengan suatu tindakan (realisasi) tanpa adanya pengingkaran (jujur dalam bertindak).

Dalam hal ini umat Islam diharapkan untuk bershalawat karena bila seluruh elemen masyarakat bershalawat keberkahan akan datang. "Dan insyaallah keberkahannya akan menjaga kita didunia dan diakhirat". Hal yang menarik yakni mengajak untuk mensyukuri atas apa yang kita dapatkan.

Menurut M. Quraish Shihab dalam mengutip pandangan Ar-Raghib AlIsfahani salah seorang pakar bahasa Al-Qur'an sekaligus penulis buku $A l$ Mufradat Fi Gharib Al- Quron yang fenomenal, menjelaskan bahwa kata “ syukur" mengandung arti "gambaran dalam benak tentang nikmat dan menampakkannya kepermukaan". Lebih lanjut, kata ini menurut Ulama' berasal dari "syakara" yang berarti "membuka" sehingga ia merupakan lawan 
dari kata "kafara" (kufur) yang berarti menutup (salah satu artinya adalah) melupakan nikmat dan menutup-nutupinya.

Kata kunci dari syukur yakni suka berterima kasih, tahu diri, tidak sombong, dan tidak lupa akan tuhannya. Bagi seorang muslim, kunci syukur itu adalah ingat Allah. Di dalam kaitan ini, M. Quraish Shihab menegaskan bahwa syukur mencakup tiga sisi. Pertama, syukur dengan hati yakni kepuasan batin atas anugerah. Kedua, syukur dengan lidah, yakni dengan mengakui anugerah dan memuji pemberiannya. Ketiga, syukur dengan perbuatan yakni dengan memanfaatkan anugerah yang diperoleh sesuai dengan tujuan penganugerahnya.

Di sini, syukur bukanlah kata benda mati. Syukur juga bukan kata sifat saja, tetapi syukur merupakan kata kerja yang perlu bukti tindakan nyata hingga akhir hayat kita. Secara lisan, praktik syukur bisa dibuktikan dengan mengucapkan kata-kata yang baik sekaligus pujian hanya untuk Allah. Dalam tindakan ini, syukur ditandai dengan upaya sungguh-sungguh dalam memanfaatkan apa saja yang bisa kita lakukan untuk kemanfaatan dan kemaslahatan semua.

Lebih lanjut, syukur secara bahasa dimaknai sebagai upaya membuka dan mengakui diri, mengakui apa yang kini diperoleh dan dirasakan semua dari Allah, oleh Allah pada akhirnya untuk Allah. Seperti ungkapan Alhamdulillah yang berarti segala puji untuk Allah merupakan ekspresi kejujuran. Semakin sering kita mengucap Alhamdulillah, sebetulnya melatih diri kita dalam bersikap jujur dalam hubungannya dengan Allah.

Hal ini berbeda ketika kita jarang atau belum mengucapkan Alhamdulillah. Bisa saja, kita lupa alias kurang menyadari betapa pentingnya kita mengucapkan dan mengucap syukur Alhamdulillah sehingga ekspresi kejujuran lahiriah dan batiniah sebagai ciptaan sekaligus hamba Allah yang maha pengasih.

Secara praktis, ekspresi syukur dapat diwujudkan dengan memanfaatkan segala apa yang telah kita punya atau miliki untuk kebaikan-kebaikan bagi diri, 
keluarga, masyarakat, bangsa, Negara dan orang yang berada disekitar kita. Mata kita untuk melihat yang baik-baik sekaligus membaca dan memahami ayat-ayat kekuasaan Allah. Kaki digunakan untuk berjalan menuju kebaikan. Telinga untuk mendengar yang baik. Hati untuk merasakan, menghayati dan mensyukri nikmat-Nya.

Tidak hanya itu, nikmat sehat yang kita rasakan, misalnya dapat kita manfaatkan untuk bekerja dan beribadah dengan sungguh-sungguh. Nikmat harta yang kita punya, bisa kita manfaatkan untuk saling berbagi, berinfak dan beramal jariyah untuk tabungan dan investasi akhirat nanti. Nikmat iman yang kita hayati perlu terus kita syukuri dengan cara berdo'a dan berusaha terus menerus berupaya mengamalkan ajaran Islam dengan ikhlas Lillahi ta'ala (Mahfud, December 2014).

Dari kutipan diatas dapat ditegaskan bahwa syukur disini dapat membuat kita berusaha konsisten dalam mengamalkan syukur dalam dunia nyata sekaligus dunia maya. Dalam kondisi ini, disadari bahwa syukur merupakan proses dinamis yang tidak pernah ada ujung usainya (never ending proces). Semakin banyak bersyukur, semakin berlipat ganda kebahagiannya yang dirasakan. Di sinilah, pemahaman yang sesuai dengan kepentingan, kebutuhan dan tantangan yang dihadapi, diharapkan pengalaman syukur kepada Allah benarbenar bermula dari ketulusan hati dan keikhlasan beramal yang hakiki sehingga bermanfaat dalam kehidupan manusia sendiri baik di dunia maupun di akhirat. Seperti yang di sampaikan oleh saudara Jami', selaku wakil ketua jam'iyah shalawat ketika peneliti melakukan wawancara. Hasil wawancaranya sebagai berikut:

"Ketika kita berkumpul disuatu majlis, maka didalam suatu majlis pasti kita berkumpul dengan orang banyak, disitulah kita harus bisa menyesuaikan diri kita. Misalkan ketika kita mengikuti jam'iyah shalawat didalam kegiatan itu pasti terdapat beberapa orang yang lebih tua, dan muda disitulah kita belajar menghargai orang lain dalam bahasa jawa "unggah -ungguh" tawadhu'nya kepada yang lebih tua, selain itu norma-norma yang lain juga perlu 
diperhatikan, misalnya shalawatan biasanya diadakan di masjid atau mushollah disitulah etikanya terutama bagi yang laki-laki yang merokok ketika kita berada dalam suatu majlis shalawat, ketika kita shalawatan masa sambil merokok".

3. Faktor Pendukung dan Penghambat yang Dihadapi dalam Upaya Pembentukan Akhlakul Karimah Remaja Melalui Kegiatan Jam'iyah Shalawat Ds. Jatirejo Kec. Diwek Kab. Jombang

Adapun faktor pendukung yang dihadapi oleh remaja desa Jatirejo dalam upaya pembentukan akhlakul karimah melalui kegiatan jam'iyah shalawat, yaitu:

a. Adanya fasilitas berupa musholla dan alat music yang dapat dipergunakan untuk melakukan kegiatan.

b. Adanya motivasi atau minat yang dimiliki oleh remaja sehingga dalam proses pembentukan akhlak berlangsung, dapat memberikan pengaruh besar pada dirinya sehingga mampu menjadikan dirinya tergerak untuk mengikuti kegiatan.

Hal ini dijelaskan pada buku interaksi dan motivasi belajar karangan Drs. Sardiman A.M bahwa dalam belajar sangat diperlukan adanya motivasi. Motivasstion is an essential conditional of learning. Hasil pembelajaran akan menjadi optimal, kalau ada minat. Adanya minat atau motivasi dalam diri, akan mudah dalam membentuk akhlak. Jadi, adanya minat para remaja yang meningkat menjadikan alasan terbentuknya kegiatan ini (Sadirman)

Antusias yang dimiliki para remaja menjadi faktor pendukung jam'iyah shalawat dalam membentuk akhlak remaja. Dengan adanya antusias yang tinggi tentunya tidak akan disia-siakan oleh jam'iyah shalawat. Sehingga selain antusias yang dimiliki remaja mudah untuk dikondisikan. Hal-hal yang menjadi faktor pendukung antara lain:

1) Tingginya antusiasme remaja terhadap shalawat

2) Kekompakan yang sudah ada sejak awal

3) Mudahnya pengondisian

4) Semangat berkumpul yang tinggi jika ada kehadiran lawan jenis 
5) Antusias remaja ketika penyampaian materi

6) Dukungan dari ketua ranting organisasi NU Jatirejo dan masyarakat

Oleh karena itu yang mendukung pembentukan akhlak pada remaja terbentuk melalui dukungan dari faktor lingkungan yaitu adanya dukungan dari ketua ranting organisasi NU Jatirejo dan masyarakat. Dari segi citra diri yaitu adanya semangat berkumpul yang tinggi jika ada kehadiran lawan jenis. faktor ini merupakan hal wajar bagi kalangan remaja, dimana mereka masih diusia yang sangat muda. Namun, meski adanya kehadiran lawan jenis mereka juga dapat dapat memilah mana yang baik dan buruk serta terdapat pengawasan dari jam'iyah terutama dari ketua ranting yang menekankan dari segi lawan jenis.

Sedangkan faktor penghambat dari upaya pembentukan akhlakul karimah remaja adalah menurunnya motivasi dalam mengikuti kegiatan. Karena, menurut Drs Sadirman A.M seseorang akan akan berhasil dalam merubah dirinya, kalau pada dirinya sendiri ada keinginan untuk merubah kedalam kebaikan. Inilah prinsip dan hukum pertama dalam kegiatan pendidikan. Keinginan atau dorongan untuk belajar inilah yang disebut motivasi.

Dibawah ini hal-hal yang menjadi faktor penghambat jam'iyah yaitu:

1) Penyalah gunaan handphone, atau alat telekomunikasi

2) Media penyiaran elektronik berupa televise dan lain sebagainya

3) Kurang mendapat pengawasan dan perhatian dari orang tua

4) Pergaulan yang kurang mendukung

5) Menurunnya motivasi belajar

6) Latar belakang pendidikan yang rendah

Lingkungan juga sangat berpengaruh terhadap perkembangan akhlak seorang anak dan juga remaja. Sesuai pendapat saudara Aziz bahwa sosial dan cultural memainkan peranan penting dalam pembentukan atau pengondisian tingkah laku kenakalan remaja. Perilaku anak-anak remaja ini menunjukkan tanda-tanda kurang atau tidak adanya konfornitas terhadap norma-norma sosial, mayoritas para pelaku kenakalan tersebut dibawah usia 21 tahun. 
Hal ini sama sekali tidak dapat dipungkiri, karena bagaimanapun lingkungan merupakan tempat dimana dia tumbuh dan mendapat stimulasi dalam menjalani setiap detik kehidupan, lingkungan juga merupakan tempat diamana belajar berinteraksi dengan dunia luar sebagai bentuk pemenuhan kebutuhan sosial, yang secara tidak langsung dapat mempengaruhi perilaku mereka sehari-hari, sesuai dengan apa yang dipelajari dari lingkungan sekitarnya.

\section{Kesimpulan}

Upaya pembentukan akhlakul karimah remaja melalui kegiatan jam'iyah shalawat Ds. Jatirejo Kec. Diwek Kab. Jombang, upaya-upaya yang dapat dilakukan untuk membentuk akhlakul karimah adalah: Melalui proses pembiasaan. Pergaulan dengan orang-orang yang yang berbudi pekerti luhur (berakhlak mulia) yang berada di lingkungan sekitar tempat tinggal dan Melalui proses pengajaran (siraman rohani). remaja berperilaku baik seperti contoh sopan kepada yang lebih tua serta dapat memilah-milah sesuatu yang baik dan yang tidak baik untuk dilakukan. Faktor pendukung yang dihadapi oleh remaja desa Jatirejo dalam upaya pembentukan akhlakul karimah remaja melalui kegiatan jam'iyah shalawat yakni adanya fasilitas yang dapat mendukung kegiatan, dan yang terpenting adanya motivasi atau minat yang dimiliki oleh remaja sehingga dalam proses pembentukan akhlak berlangsung dan menjadikan dirinya tergerak untuk mengikuti kegiatan. Sedangkan, faktor penghambatnya adalah menurunya motivasi dalam mengikuti kegiatan dan juga faktor lingkungan karena pergaulan yang kurang mendukung.

\section{Daftar Rujukan}

Abdurrahman, M. 2016. AKHLAK: Menjadi Seorang Muslim Berakhlak Mulia. Jakarta: Rajawali Pers.

Aceh, A. 1991. Pendidikan Sufi Sebuah Karya Mendidik Akhlak Manusia Karya Filosof Islam di Indonesia. Solo: CV. Ramadhani. 
Agustina, Hendriati. 2006. Psikologi perkembangan (pendekatan ekologi kaitannya dengan konsep diri pada remaja). Bandung: Refika Aditama.

Al'akk, Syekh Khalid bin Abdurrahman. 2006. Cara Islam Mendidik Anak. Yogyakarta: Ar-Ruzz Media.

Al-Ghazali, I. 2011. Ihya Ulumuddin Jilid III. Bandung: Marja.

Ali, Syed. Amir. 1992. Etika Dalam Islam. Surabaya: Risalah Gusti.

Anwar, Rosihan. 2010. Akhlak Tasawuf. Bandung: Pustaka Setia.

Arikunto, S. 2010. Prosedur Penelitian Suatu Pendekatan Praktik. Jakarta: Rineka cipta.

As, Asraman. 1994. Pengantar Studi Akhlak. Jakarta: PT Raja Grafindo.

Beni Ahmad Saebani, A. H. 2010. Ilmu Akhlak. Bandung: Pustaka Setia.

Dahri, A. diakses 25 maret 2016. Antara Jamaah dan Jam'iyah.

Damaianti, Syamsuddin. A.R \& Vismaia. (009. Metode Penelitian Pendidikan Bahasa. Bandung: PT Remaja Rosdakarya.

Djatmika, Rahmat. 1996. Sistem Etika Islam. Jakarta: Pustaka Panimas.

Firdaus, Firdaus. Al-Dzikra 2017. Membentuk Pribadi Berakhlakul Karimah secara Psikologis. https://www.neliti.com/id/publications/1708009/membentuk-pribadiberakhalakul-karimah-secara-psikologis , 59-61. diakses pada tanggal 27 oktober 2019.

Gizalbi, Sidi. 1976. Masyarakat Islam, Pengantar Sosiologi dan Sosiografi Islam. Jakarta: Bulan Bintang.

Hasan, M. 2002. Membentuk Pribadi Muslim. Yogyakarta: Pustaka Nabawi.

Ilyas, Yunahar. 2004. Kuliah Akhlak. Yogyakarta: Lembaga Pengkajian dan Pengamalan Islam/LPPI.

Jaelani, Ahmad. 2015. kisah para pengamal doa, zikir dan Shalawat. Yogyakarta: alFatihah.

https://www.kompasiana.com/www.dahrilogic.com/56f46f61cd927353048b4575/antara -jamaah-dan-jamiyah Diakses

Jamhari, A. Zainudin \& Muhammad. 1999. al-islam 2: Muamalah dan Akhlak. Bandung: Pustaka Setia. 
Ali Mustofa dan Ika Khoirunni'mah

Kinosyan. 2002. Love Banget Sama Shalawat. Jakarta: Grasindo.

Mahmud, Ali. Abdul Halim. 2004. Akhlak Mulia. Jakarta: Gema Insani.

Mustafa. 1997. Akhlak Tasawuf. Bandung: CV Pustaka Setia.

Moleong, L. J. 2005. Metode Penelitian Kualitatif. Bandung: Remaja Rosda Karya.

Nata, A. 2009. Akhlak Tasawuf. Jakarta: Rajawali Pers.

Qadiri, Fadilah Ibnu Shidiq al. 2009. Amalan Ampuh dalam 24 jam. Yogyakarta: PT Buku kita.

Rohman, t. S. 2007. Keutamaan Shalawat Untuk Nabi. Keutamaan Shalawat Untuk Nabi, terj. Sholaludin Abdul Rohman (penerbit Darul Qosim) Islam house.com

Sadirman. 2012. Interaksi dan Motivasi Belajar Mengajar. Jakarta: PT Raja Grafindo Persada.

Saebani, Beni. Ahmad. 2008. Metode Penelitian. Bandung: CV Pustaka Setia.

Salim, Ibnu. Muhammad. 2008. Keajaiban Shalawat: Melepas Rindu Pada Rasulullah SAW dan Menjemput Syafaat di akhirat. Jakarta: Penerbit Hikmah.

Shihab, M. Q. 2007. Waawasan Al-Qur'an. Bandung: PT Mizan Pustaka.

Sugiyono. 2011. Metode Penelitian Pendidikan Pendekatan Kuantitaif, Kualitatif, dan $R \& D$. Bandung: alfabet.

Sugiyono. 2013. Memahami Penelitian Kualitatif. Bandung: Alfabeta.

Sugiyono. 2014. Metode Penelitian Pendidikan Kuantitatif, Kualitatif dan R\& D. Bandung: Alfabeta.

Supendi. 2007. Pendidikan Dalam Keluarga Lebih Utama. Jakarta: Lentera Jaya.

Soetjiningsih. 2004. Tumbuh Kembang Remaja dan Permasalahannya. Jakarta: CV Sagung Seto.

Soparno, Paul. 2015. Pendidikan Karakter Disekolah. Yogyakarta: PT Kanisius.

Ulwan, A. N. 1991. Pedoman Mendidik Anak dalam Islam. Semarang: Asyifa.

Umari, Barmawi. 1976. Materi Akhlak. Solo: Ramadhani.

Wahid, Ahmadi. 2004. Risalah Akhlak. Solo: Era Intermedia.

Wargadinata, Wildana. 2010. Spritual Shalawat. Malang: UIN-MALIKI Press.

Ya'qub, Hamzah. 1993. Etika Islam. Bandung: Diponegoro. 